
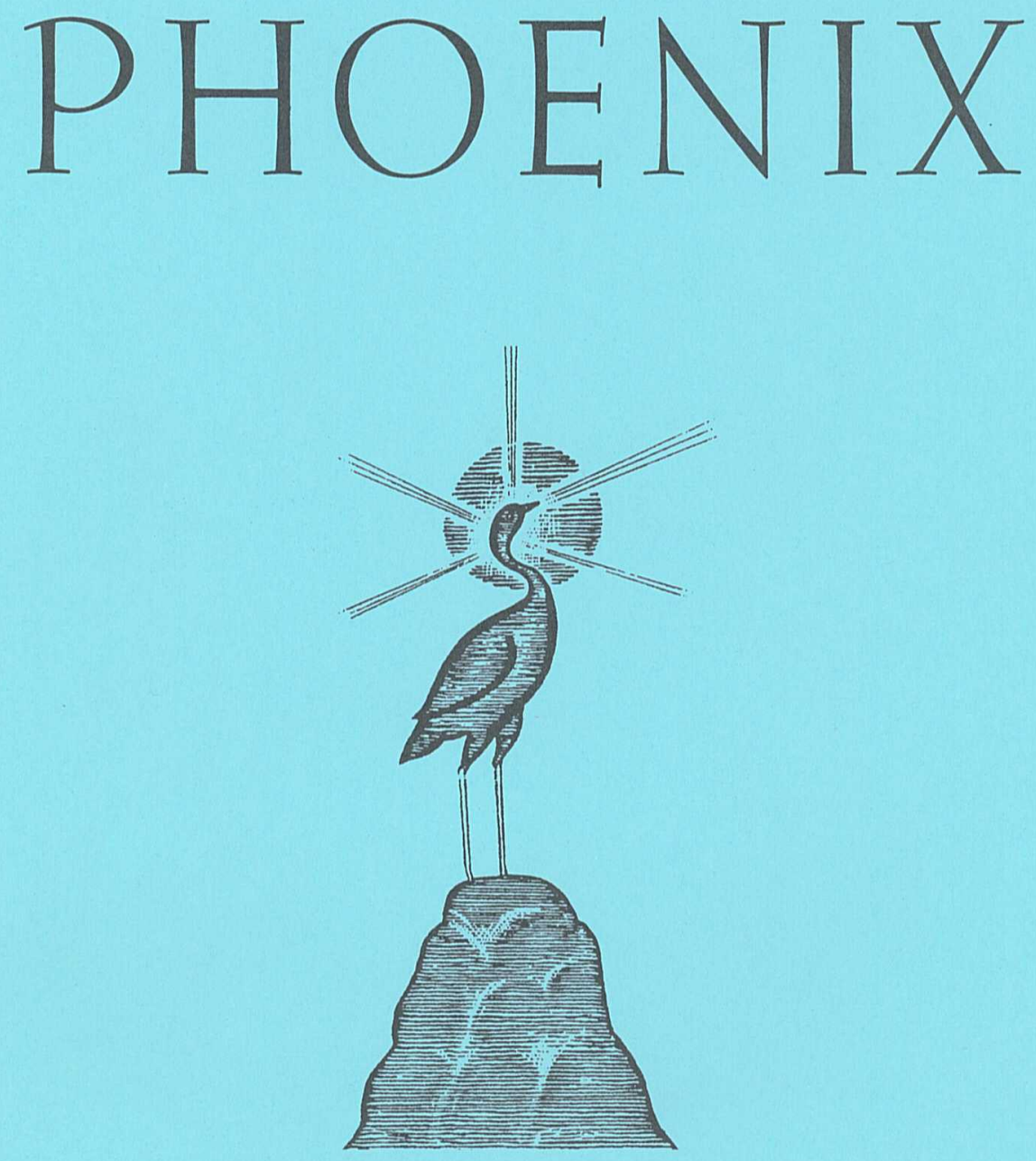

LXIX No. 1-2, Spring-Summer/printemps-été 2015

Classical Association of Canada Société canadienne des études classiques 


\section{AESCHYLUS ON DARIUS AND PERSIAN MEMORY}

\section{Michael Sampson}

I

$\mathbf{I}_{\mathrm{N}}$ the fifth воOK OF His HISTORIEs, Herodotus describes Darius' reaction to the burning of Sardis during the Ionian revolt. Paying little mind to the Ionians themselves, the Persian king is focused, from the start, solely on the Athenians:

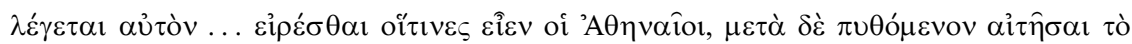

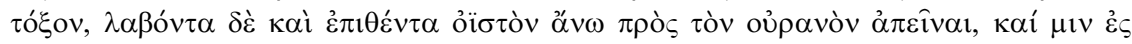

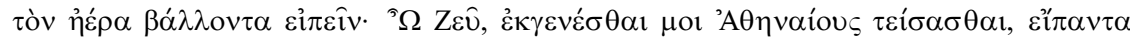

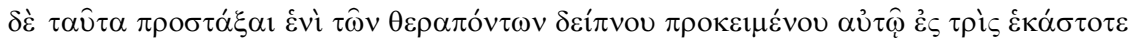

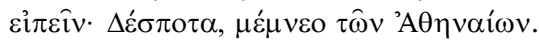

He asked who the Athenians were, and after receiving his answer he requested his bow. After taking it and loading an arrow, he shot it up towards heaven, and as it flew into the atmosphere, he exclaimed: "O Zeus, may it be granted to me to take vengeance on the Athenians." When he had said these things, he commanded one of his attendants to remind him three times whenever a meal was set before him, "Master, remember the Athenians."

According to Herodotus, this memory motivates the Persian campaigns of 490 and 480. The latter expedition is particularly notable: even though Xerxes has by this time succeeded his father as monarch, Herodotus continues to emphasize the depth of his memory (as well as the grudge it sustains) amongst his various reasons for burning Athens (7.8). ${ }^{1}$

Herodotus' representation of Persian memory makes a convenient starting point for a discussion of Aeschylus' Persae, a tragedy whose production in 472 predates Herodotus' prose chronicle by several decades. For one thing, the play is no less concerned with how (and what) the Persians remember: ${ }^{2}$ while it dramatizes the arrival of the news from Salamis and the nostos of Xerxes, the more distant past looms large-most manifestly in the ghost of Darius that haunts the play. But the Aeschylean representation is also more complex than Herodotus',

Earlier versions of this paper were presented to audiences at Temple University, the University of Manitoba, and the 106th CAMWS meeting in Oklahoma City. I am grateful to those audiences, to Bernd Steinbock, Rory Egan, and to Phoenix's referees for helpful comments. The text is West's (1998) unless otherwise noted, and translations are my own.

${ }^{1}$ Herodotus also includes the lobbying of the Aleuadae and the Pisistratid Hippias amongst the motivations (7.6).

${ }^{2}$ As Edith Hall (2007: 1) notes immediately in the preface to her edition, memory is "one of the many themes to have been neglected by critics." Grethlein (2007: 365) echoes the sentiment, noting the preponderance of the stem $\mu v \eta-$. My argument will pursue a far less theoretical path than his, though the two are in several respects complementary.

PHOENIX, VOL. 69 (2015) 1-2. 
for it is not simply Persian memory which is at issue. Performed as it was before a predominately Athenian audience, ${ }^{3}$ the play's themes of memory and the reception of recent history reverberate outside the dramatic action, as well: the play constructs a divide between the historical and the dramatic, namely, between the Athenian audience and the Persian characters' respective memories. This divide complicates interpretation: ${ }^{4}$ in contrast to Herodotus' depiction of Darius and Xerxes obsessing over past injuries, the Aeschylean Persians, for all their wailing and derision of Xerxes following the news from Salamis, have a curious relationship to Darius' defeat at Marathon a decade prior. Instead of viewing Darius as the historical precursor for his son's failure, Aeschylus' Persians (and one ought not to confuse them with historical Persians any more than one should equate the dramatic action with history) hold him up as a foil: even in death, his majesty and achievements are idealized while his shortcomings are minimized. For an Athenian audience in 472, however, victory at Marathon in 490 set the precedent for Salamis, and the play's dramatized glorification of Darius therefore appears calculated to disappoint its expectations. ${ }^{5}$ Unlike Herodotus' later narrative, Persian memory in Persae is faulty: as Aeschylus' audience is uniquely capable of appreciating, they do not "remember the Athenians" very well at all.

The following treatment of Aeschylus' representation of Persian memory proceeds on several interrelated fronts. In the course of investigating the Persians' attitude towards Darius and the past, I analyze their imperial ideology as imagined and dramatized by Aeschylus. Simply put, the Persians conceive of the past and the present as continuous, and of history as consistent, regular, and paradigmatic. ${ }^{6}$ In this "timeless present," imperial prosperity both ensues from and predicts further prosperity: the same, unfortunately, goes for imperial calamity. Thus, the Persians' typically positive recollection of Darius' reign goes hand in hand with an ideological confidence in the continuity of the empire, while Salamis and Xerxes, by contrast, rupture that concept of an imperial destiny, simultaneously rewriting an assumed history and portending ill for the future. But to the extent that Aeschylus emphasizes its relationship to ideology, Persian memory (and, specifically, the case of Marathon) is problematic for the audience, as well. Thus, in the final portion of the paper, I consider the play's

${ }^{3} \mathrm{Cf}$. the argument of the late Kate Bosher (2012: 97-111) regarding the possibility of an original production in Sicily.

${ }^{4}$ Grethlein (2007: 373-374, 377) remarks upon the play's "double audience" as well. Cf. Hopman (2009: 371-375), who argues that the play "constructed an increasingly proximity between Persian Elders and Athenian audience" (371), which she goes to describe as the Hellenization of the chorus.

${ }^{5}$ On the continuity between Darius and Xerxes in Herodotus, see Saïd 1981.

${ }^{6}$ To use the language of Grethlein (2010: 9-11), these are modes of memory: the continuous is created by traditions, while the regular is created by patterns or examples. This article, in many respects, supplements and modifies Grethlein's arguments about the play (2010: 74-104). 
reception in the Athens of 472: with recourse to what historians and anthropologists term "collective" or "social" memory, ${ }^{7} \mathrm{I}$ set my interpretation of the play in the historical context of democratic debates and military activities in the 470 s, and propose a new analysis of its possible implications for the polis before which it was produced.

The specter of Darius haunts the dramatic action of the Persae, especially its theme of memory. When Atossa first appears at the start of the first episode, she describes how she has left the bedchamber they shared and expresses an unusual fear:

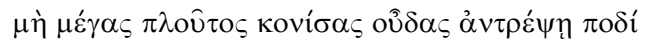

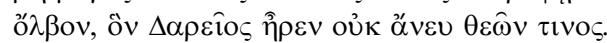

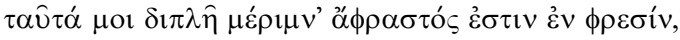

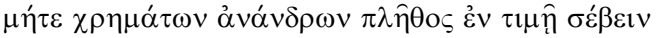

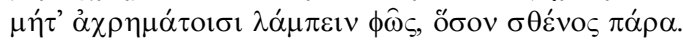

[I fear] that great wealth may kick up dust and overturn with its foot the prosperity which Darius (not without some god's help) increased. These things-a twofold concern-are inexpressible in my heart: that the majority won't revere wealth unaccompanied by human capital; and that in proportion to their strength, the light won't shine for those who lack wealth.

The chorus had raised a similar anxiety in the parodos, but Atossa's arrival articulates the theme of Persian prosperity and the possibility of its undoing. Darius is emphasized: Atossa traces the acquisition of the empire's prosperity specifically to her late husband (163-164), and it is no accident that her anxiety about its undoing arises in his absence. Yet there is irony in her words; while her spectacular advent reifies the ostentatious, imperial wealth of which she speaks, ${ }^{8}$ so too does it reflect current circumstance, as well. With her son off at war and her husband deceased, Atossa lacks the male custodian(s) on whom the pomp that attends her depends and to whom it is owed. In the typically loaded fashion of Aeschylean language, her fear about wealth unaccompanied by human

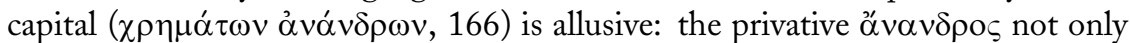
anticipates the future state of the empire (i.e., as "unmanned" or "lacking human capital") but also her own literal (and the state's metaphorical) widowhoodi.e., "lacking a husband," or "king." " As Atossa stands on her chariot before the

\footnotetext{
${ }^{7}$ On "collective" and "social" memory (and its application to the study of antiquity, in particular), see Steinbock 2012, 2013; Alcock 2002. Though most prefer the label "social" memory as opposed to "collective" memory, this paper will speak of the Persians' collective memory since Aeschylus is, to my mind, in fact reifying a unified Persian perspective: see Steinbock 2012: 8-19. For social memory in general, see (among others) Assmann 1995; Burke 1989; Fentress and Wickham 1992; Halbwachs 1980; and Misztal 2003: 50-98.

${ }^{8} \mathrm{Cf} .607-609$. On the impressive staging of her arrival with chariots and supernumeraries, see Taplin 1977: 70-80, esp. 79.

${ }^{9}$ Wealth unaccompanied by human capital is as problematic for Atossa as the second element of her "double concern"-namely, manpower lacking wealth. See Garvie 2009: 109-111, ad 166-167.
} 
chorus in all her finery, her words cast her as both the embodiment of her late husband's prosperous reign and as a harbinger of the doom in which her son's expedition will result. ${ }^{10}$

The juxtaposition of prosperity and calamity is also a juxtaposition of past and the present, of Darius and Xerxes. Atossa's famous dream (176-199), in which Xerxes attempts to yoke a Greek and a Persian together but is thrown from his chariot by the Greek's defiance, illustrates as much: within this vision, Darius pities his son, and Xerxes rends his garments in grief. As far as history and the play's Athenian audience are concerned, the dream is even more ominous than Atossa's unease about $\chi \rho \eta \mu \alpha \tau \alpha$ öv $v \alpha \delta \rho \alpha$ : Xerxes' expedition against Greece will fail. But one should overlook neither the presence of Darius (and thus, the past), nor how he is absolved of Xerxes' undoing: in accordance with how Atossa recalls his reign, his display of pity suggests that Xerxes' failure disappoints and falls short of his own achievements, a point reinforced by the disparity between Atossa's wardrobe and the tearing of Xerxes' clothing. From the perspective of past prosperity, Atossa's subconscious fear is anomalous-even unprecedented.

The prominence of Darius in these two passages is neither an accident nor exceptional; Aeschylus repeatedly characterizes the Persians through their memories of the king. In the face of uncertainty, the dramatis personae take recourse to him, both consciously and subconsciously. So, for example, in response to Atossa's entry, the chorus' interpretation of her dream consoles her by way of invoking the king:

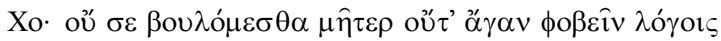

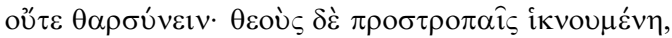

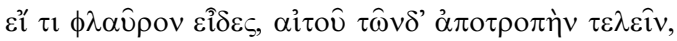

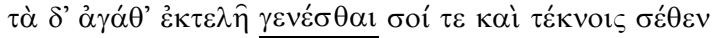

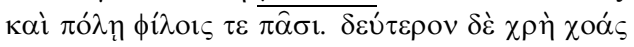

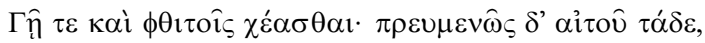

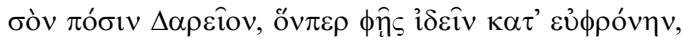

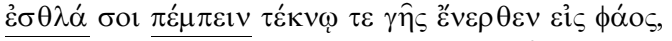

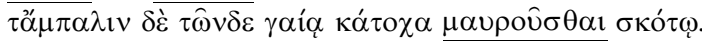

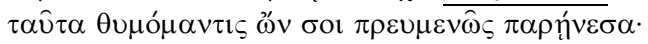

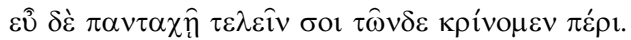

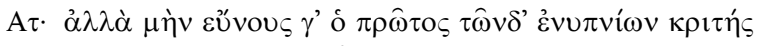

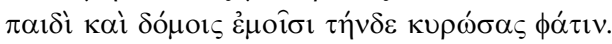

Ch: Mother, we do not want to frighten or reassure you excessively with our words. If you saw something bad, beseech the gods with invocations and ask them to accomplish the prevention of these things, and that good things come to be for you, your children, the polis, and all your relations. Next, you ought to pour libations to Gaia and to the dead. Graciously request these things, that your husband Darius, whom you say you saw in the dream, send good things up to the light from below the earth for you and your son, and that their opposites be darkened, secure in the

${ }^{10}$ See further the discussion of lines 284-289 (below, 31-32). 
murky earth. I recommend these things to you kindly, prophesying from my thumos, and judge concerning them that they will turn out entirely well for you.

At: You, the first judge of these nocturnal visions, are indeed favorable-for my son and my home-in your interpretation of the utterance.

The chorus begins by espousing moderation and, on the assumption that the dream bodes ill, prescribes a ritual remedy whose success would entail (a) the gods warding off the bad, and (b) a positive result arising in its stead (218-220; cf. 201-206). Given Atossa's anxiety, its caution and counsel are unremarkable. But curiously, the chorus then recommends an additional course of action: it also prescribes recourse to the dead, amongst whom Darius is especially potent (220-224).

While the additional recommendation seems to aim at much the same outcome as the first, it is a mistake either to interpret the two stages of the chorus' advice as redundant or to overlook its emphasis on the deceased monarch's effi-

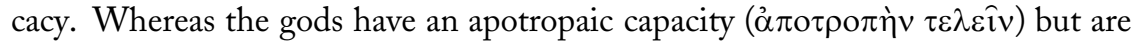
not (grammatically speaking) the agents of good things "happening" or "coming to be," Darius, by contrast, is personally capable of sending up good things $(\dot{\varepsilon} \sigma \theta \lambda \grave{\alpha} \ldots \pi \dot{\varepsilon} \mu \pi \varepsilon \imath v) .{ }^{11}$ The chiasmus links the chorus' two prescriptions, producing an about-face from its initially cautious response: ${ }^{12}$ so reassuring is the recommended recourse to Darius that the chorus ends up optimistically predict-

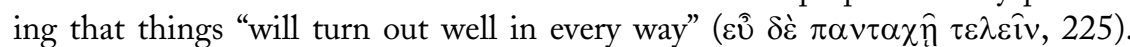
The about-face is emotional as well: Atossa is so reassured by the prospect of his intervention from beyond the grave that she also considers the explanation of her vision to be favorable (226-227).

The play's representation of Darius permits a hermeneutics of the Aeschylean Persians. Both Atossa and the chorus conceive of him as similar-but not identical - to a god. ${ }^{13}$ Much as entreaty and prayer can be addressed to a divinity, so too can they be addressed to the dead king (especially in the current, anxious circumstances). But while the power to deflect calamity belongs to the gods, the dividends of Darius' activity - in death as in life - are success and prosperity. Herein one glimpses the potency of Persian memory: in the face of anxiety about Xerxes' expedition, the Persians do not simply look to the past to fawn upon Darius, but also find there both an ideological foundation for the present and for future success. ${ }^{14}$ Because Atossa and the chorus desire

\footnotetext{
${ }^{11}$ Muntz (2011: 258) overlooks how the chorus' second prescription (220-222) specifies Darius as the agent of prosperity.

${ }^{12}$ What emerges is the two complementary sides of a coin: when Atossa speaks of the wealth that Darius amassed "not without some god's help" (163-164), she describes both the human achievement (namely, success and accumulation) and the gods' role in it (the prevention of failure).

${ }^{13}$ For more on this point, see (most recently) Muntz 2011.

${ }^{14}$ On these strategies for coping with contingency, see Grethlein 2010: 9. The chapter which focuses specifically on Persae, interestingly, considers contingency of chance more than the Persians' methods of addressing it (2010: 74-104).
} 
the perseverance of the prosperity they attribute to him, their expectations are buoyed by recalling him as its agent. One glimpses a timeless, unified present: linking prosperity to Darius and the past secures its continuation in the present and future. ${ }^{15}$

The connection between past and present recurs when Darius irrupts into the dialogue for a third time. As her exchange with the chorus proceeds, Atossa inquires about Athens, and her focus on the here and now (as well as her ignorance of recent history that it entails) produces a startling conclusion:

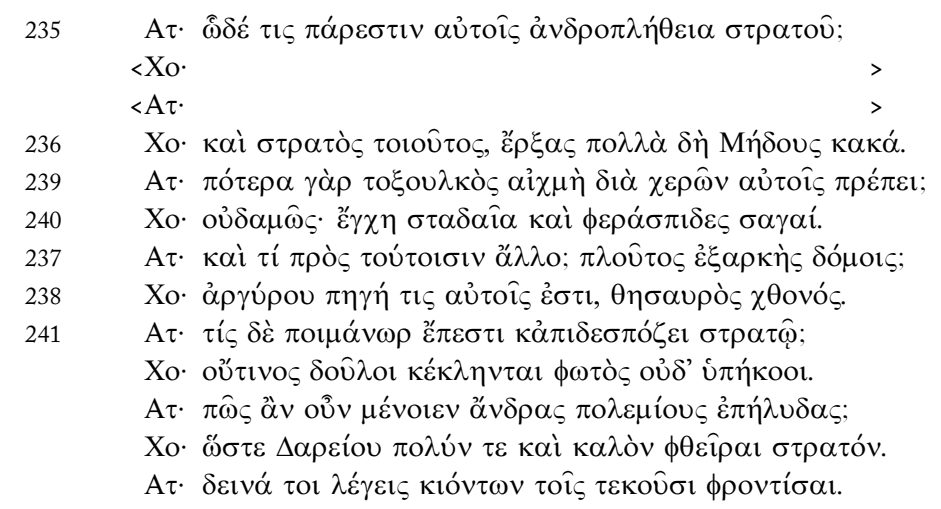

At: So they have some abundance of manpower for their army? $<\mathrm{Ch}$ :

$<$ At: $>$

Ch: The army is the kind as to accomplish many misfortunes on the Medes.

At: Are the bow and arrow fitting for their hands?

Ch: Not at all, but spears for close quarters and shields for equipment.

At: What else in addition? Is there sufficient wealth in a palace?

Ch: They have a spring of silver, a treasury from the earth.

At: Who is the commander and master of the force?

Ch: They are called subservient or slaves to no man.

At: So how do they resist hostile invaders?

Ch: Well enough to have destroyed a vast and noble army of Darius.

At: You say terrible things for the parents of the campaigners to consider. ${ }^{16}$

Atossa's focus is emphatically on the present: in the context of the basic idea that the Athenians are capable of defeating the Persians (236), she fixates on Athens' human resources (235), technology (239), wealth (237), and command structure (241), all of which pertain to the enemy's military abilities. Her immediate concern is her son and the current expedition's success: she shows no sign of recognizing the chorus' allusion to the many misfortunes ( $\pi \mathrm{o} \lambda \lambda \dot{\alpha} \ldots \kappa \kappa \kappa \alpha$. 236)

\footnotetext{
${ }^{15}$ For this kind of "timeless past," specifically as an aristocratic ethic, see Csapo and Miller 1998. See also, more generally, Gehrke 2001.

${ }^{16}$ In this passage I follow the text of Garvie (2009).
} 
wrought by the Athenian army as a specific reference to Marathon. ${ }^{17}$ Only at the climax of the exchange, in which the chorus invokes the defeat at Marathon in all but name, does she appear to recall Athens, but even then, her focus remains emphatically on what defeat signifies in the present. The gist of her scolding rebuke ("You say terrible things for the parents of the campaigners to consider," 245) is that the memory of Marathon will dishearten and unnerve the parents of those currently off on campaign-including, of course, herself. ${ }^{18}$

The reminder's impact on the here-and-now produces another emotional about-face. Whereas the chorus' initial suggestion of recourse to Darius and the dead consoled and buoyed collective confidence in Xerxes' success (215-227), the recollection of Marathon and the events of 490 sees the Persians relapse into anxiety. The injury is ideological: so long as the memory of Darius' reign as one of wealth and prosperity persisted, it propagated optimism: thus, the reminder of Darius' beneficence was enough to console Atossa in the face of her disturbing dream. But with the irruption of the reminder of Marathon, the ideology which expects Xerxes' success and imperial prosperity is shattered. In the Persians' collective consciousness, the past is directly implicated in the present: a memory of Darius can just as easily doom Xerxes as it can inspire the expectation of his success. ${ }^{19}$

Such moments of apprehension pop up especially in the first half of the play, but they do not, typically, last long. ${ }^{20}$ Persian ideology, rather, links present and future successes with the collective memory of the past. Consider, for example, a particularly optimistic portion of the parodos:

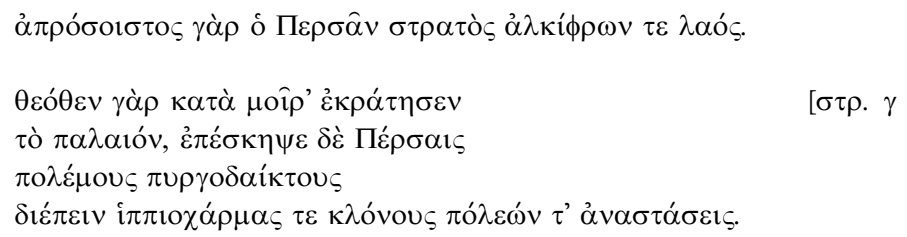

(91-92, 101-107)

The Persian army is irresistible and its people brave of heart. For long ago did divinelyappointed fate prevail, and it directed the Persians to accomplish tower-toppling wars, the clamor of horsemen, and desolations of cities. ${ }^{21}$

The chorus lays imperial ideology bare: military expansion is a historical reality that approaches divine calling. ${ }^{22}$ In other words, Persia is not simply exceptional,

${ }^{17}$ So Hall 2007: 127, ad 236.

${ }^{18}$ Sommerstein (2010: $50-51$ ) and Dimopoulou (2010: 239 ) are similarly sensitive to the importance of the present to Atossa.

${ }^{19}$ Even though Datis led the Persian campaign of 490, Persae does not name him. Instead, the play equates Darius with the battle of Marathon.

${ }^{20}$ Grethlein (2010: 79-80) tracks the emotional oscillation in the first portion of the play.

${ }^{21}$ Again, my text follows Garvie (2009).

${ }^{22}$ Kantzios (2004: 7) similarly discusses the empire's expansionism. 
but its record of imperialism and military conquest has divine backing. Most important is the link between past and present on which this ideology is based: prosperity in the present is the natural extension (one might say, destiny) of a lengthy historical tradition.

The Persians' conception of their imperial destiny, underpinned as it is by the nuances of their collective memory, is at the heart of some of the more curious (and oft-remarked) features of the play, of which Atossa's stunning obliviousness to the events of $490(235-245)$ is the chief exhibit. Marathon poses a problem because it contradicts both Persian imperial ideology as well as the particular memory of Darius sustained thereby. But it is not simply the case that the recollection of a historical defeat has the potential to destabilize the timeless present; in the aftermath of Salamis, the inverse becomes true, as well. If past and present are linked in memory, we might say that traffic runs in both directions: defeat in the present impacts the constitution of the past. Consider, for example, how Persian memory is activated by the messenger's news of defeat at Salamis:

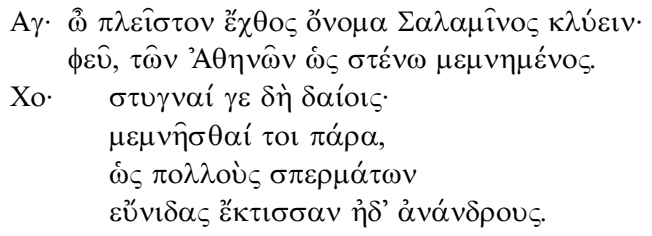

(284-289)

Me: O Salamis, a name most hateful to hear! Alas, how I lament as I remember Athens! $\mathrm{Ch}$ : She is indeed hateful-to her enemies at least. It's in my power to remember, see, how/since she has left many women unmanned and deprived of offspring.

After describing the annihilation of the Persian forces, the messenger comments on the hateful name of Salamis and how he laments in recalling Athens. Coming from a witness to the catastrophe, the sentiment is not particularly surprising. But while the chorus is eager to echo the messenger's sentiment, the fact that it does so by similarly invoking memory — despite not being witness to the defeatis curious.

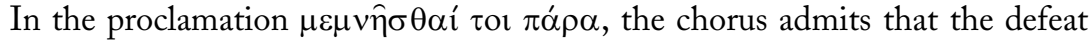
at Salamis prompts a recollection. But unpacking this assertion (which I translate with intentional awkwardness as "It's in my power to remember, see ...") as well as the subordinate clause which it governs, is difficult. At stake is the analysis of the single word $\hat{\omega} \zeta$ : if it is read as a causal conjunction ("since"), then the chorus' capacity for remembering Athens is prompted by the acknowledgment of Persian women who have been widowed and left childless (in the present and near future) by the devastation at Salamis. That is, the memory of Athens is sustained in the present by visible indicators of the empire's health. One might term this mode of memory "immediate." The alternative, that $\omega \varsigma$ functions as a relative interrogative ("how"), is "retrograde" by contrast, indicating that the 
report from Salamis instead activates a previously dormant memory. This mode is far more powerful: the messenger's report of defeat at Salamis triggers the chorus' memory of Marathon and 490, and how Athens left women widowed and childless in the past. The report prompts the chorus to acknowledge that it can, yes, remember how Athens made many bereft of offspring and husbands: the aoristic aspect of $\varepsilon^{\prime} \kappa \tau \imath \sigma \sigma \alpha \nu$ acknowledges this as a fait accompli. The reality of Xerxes' defeat in the present, in other words, triggers the acknowledgment of the precedent set by Darius.

In either reading (and, as is typical of Aeschylus, both apply), we continue to observe the continuity of past, present, and future in Persian ideology. Echoing Atossa's initial fear about $\chi \rho \eta \dot{\mu} \alpha \tau \alpha$ o̊v $\alpha v \delta \rho \alpha$ ("wealth lacking human capital," 166), the chorus now deploys the same adjective in describing the empire's lack

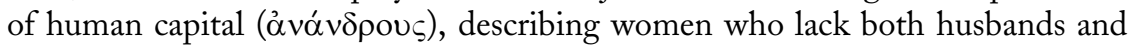
the children they would beget. ${ }^{23}$ Because the echo recalls not only the dream that prompted Atossa's onstage arrival in the present but also the events at Marathon, and because it anticipates as well a post-Salamis future in which Persia is and will continue to be devoid of husbands and offspring, it reveals the catastrophe's considerable temporal wake. In aggregate, Marathon, Salamis, and the prospect of a future emptied of men create a mutually reinforcing trend entirely at odds with Persian ideology. At risk are cultural assumptions about both Persia's superiority and the empire which the Persians conceive as divinely mandated.

Once one notices how deeply implicated in the present the past and future are, the interdependence of collective memory and ideology stands out. In response to the messenger, for example, Atossa both blames a hateful divinity for deceiving the Persians and invokes Marathon concurrently with Xerxes' defeat:

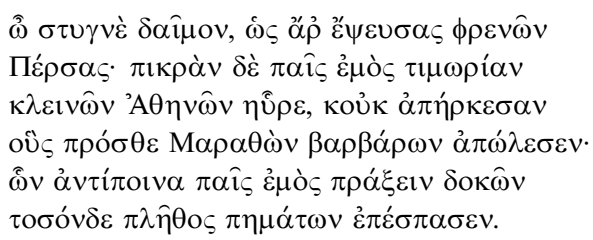

$(472-477)$

O hateful divinity, how you've deceived Persian minds, then! From the famous Athenians my son has found that vengeance is bitter: those barbarians whom Marathon previously destroyed weren't sufficient; thinking that he would bring about reprisal for those things, my son has brought on so vast a multitude of misfortunes!

Given what the Persians understand as their divine mandate for conquest and empire, Salamis represents not just disappointment, but outright deceit on the part of the gods. Yet no sooner does Atossa lay the blame at the feet of

\footnotetext{
${ }^{23}$ The adjective also appears at 298 (for unmanned posts). The term will appear in its nominal form at line 755 to denote cowardice.
} 
a divinity (like Athens, it is hateful, $\sigma \tau u \gamma v \varepsilon^{24}$ ) than she turns to her son, and attempts to both have her cake and eat it, too. The polis of whose inhabitants she was woefully ignorant less than 250 lines previous is now deemed famous ( $\kappa \lambda \varepsilon เ v \hat{\omega} \nu$ 'A $\theta \eta \nu \hat{\omega} v$ ), and the precedent set by Marathon to which she was previously oblivious is now not simply the cause of Xerxes' expedition but also the benchmark of catastrophe surpassed by it. Her memory is well and truly activated. Similarly ironic are the motivations she attributes to Xerxes: he evidently launched the campaign with confidence in success and Persia's god-given imperial destiny (how else could he have been deceived?). Yet such confidence runs contrary to her parallel assertion that he planned the campaign deliberately, in retribution for the defeat at Athens' hands. ${ }^{25}$ The paradox implicit in Atossa's lament reflects the contradictions of Persian memory; the inconsistency of ideology and history results in an inconsistent memory of Marathon-vividly recalled and passed over by turns. ${ }^{26}$

Darius remains at the heart of Persian memory, and in response to the trauma of Salamis, the deceased king's beneficence is increasingly reasserted: the two scenes that follow the messenger's report hearken back to Atossa's dream and the contrast between Darius and his successor. Thus, in the exodos, an emotional kommos laments Xerxes' failure at length, while the necromancy scene that precedes it attempts to reanimate Darius' reign (and its prosperity). By reasserting the ideological status quo and by contrasting Darius to Xerxes as the embodiment of prosperity, the necromancy scene puts all of the contradictions and paradoxes

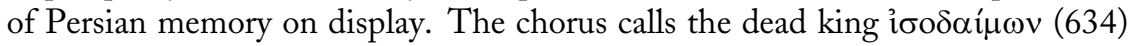
and a $\theta \varepsilon$ ó $\varsigma$ (643), flattering him in an attempt to absolve him from the taint of the present military failure:

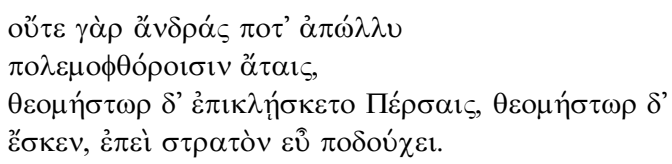

For he never used to destroy our men in a ruinous disaster of war, but used to be called "divine counselor" by the Persians. And he was a divine counselor, since he governed the army well.

Coming as it does from the same body that previously reminded Atossa that the Athenians destroyed a vast army belonging specifically to Darius (244), the

\footnotetext{
${ }^{24}$ Cf. also 347, where divine favor for Athens is similarly emphasized: "the gods preserve the

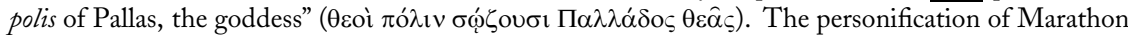
anticipates the Stoa Poikile (Paus. 1.15.3) and the vision of Epizelus (Hdt. 6.117): cf. Jung 2006: 53-54.

${ }^{25}$ See also Grethlein 2010: 83-84 on the various explanations for Xerxes' failure.

${ }^{26}$ Grethlein (2007: 372) reaches similar conclusions from a very different mode of argumentation, and subsequently argues that the passage constructs continuity between father and son (2007: 385). Schenker (1994: 284-285) considers the attitudes in terms of the people's relationship to the king.
} 
claim is curious. ${ }^{27}$ As the catastrophe of Salamis sinks in, the Persians evidently struggle to comprehend it: glorifying Darius requires inculpating Xerxes and casting his defeat as an outlying event, even as that defeat prompts the acknowledgment of Darius' misfortunes, as well. Thus, the imperfect $\alpha \dot{\alpha} \omega \dot{\lambda} \lambda \nu$ acknowledges military defeat on his part (though denying that it was habitual), while reasserting Darius' standing as a divine counselor and capable marshal in contrast to his son.

Such efforts to manage the crisis are not limited to the chorus. As Atossa subsequently laments Xerxes' defeat, her first words to the ghost also reiterate the superlative prosperity and happiness that he and the empire enjoyed:

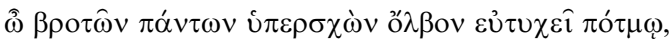

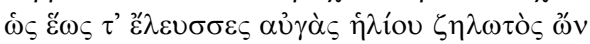

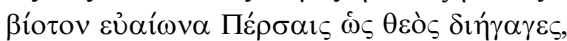

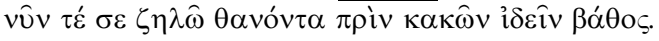

You who surpassed all mortals in happiness at your fortunate death, how you were enviable and led a happy life like a god among the Persians, so long as you beheld the rays of the sun. Now I envy you for dying before looking upon the depth of our misfortunes.

The same juxtaposition of absence (on his part) and anxiety (on hers) glimpsed earlier in the play (163-167) underlies the praise; once more Darius is likened to a god and once more misfortune appears incompatible with his reign. Even the ghost himself plays along in reasserting ideology in the face of Xerxes' defeat. $^{28}$ From Darius' perspective, as well, the disaster Xerxes has wrought is unprecedented:

$\cdots$ $\kappa \alpha ̉ \pi \varepsilon \sigma \tau \rho \alpha ́ \tau \varepsilon v \sigma \alpha \pi \mathrm{o} \lambda \lambda \grave{\alpha} \sigma \dot{v} v \pi \mathrm{o} \lambda \lambda \hat{\omega} \sigma \tau \rho \alpha \tau \hat{\omega}$,

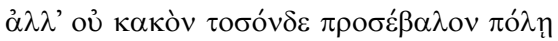
...

\footnotetext{
${ }^{27}$ The text is disputed, as editors variously read $\pi \dot{\omega} \pi \mathrm{o} \tau^{\prime}$ or $\pi \mathrm{o} \tau^{\prime}$ (the latter requires the removal of $\hat{\eta}$ in line 647 of the strophe). With the exception of Dindorf's emendation in 656, I follow West, since the imperfect $\alpha \dot{\alpha} \omega \dot{\lambda} \lambda v$ implies that defeat was not a habit of Darius' (cf. the categorical denial that oü $\tau \varepsilon \ldots \pi \dot{\omega} \pi \mathrm{o} \tau^{\prime}$ would imply).

${ }^{28} \mathrm{He}$ echoes Atossa's earlier concern that the wealth he had amassed might be lost (750-752), and also comments that there must have been something off in Xerxes' mind. But as with Atossa (472-477), the idea that Xerxes was deluded ill suits the confidence befitting a Persian commander, and Darius' explanation at 753-758 is no less vexed. Far from being deluded, Xerxes' motivations were in the mold of his predecessors, who similarly undertook campaigns of conquest.
} 


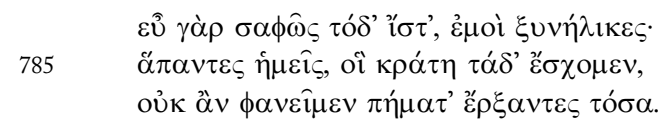

(759-764, 780-781, 784-786)

He has, accordingly, wrought the greatest deed, one that will always be remembered and of the sort that has never yet befallen this city, Sousa, or emptied it out. Never-from the time when lord Zeus granted this office, that one man in possession of a scepter of authority rule over all of sheep-nurturing Asia

...

And I waged many wars with a great host, but did not procure so vast a misfortune for the city

...

Know this thing well, my fellow elders: all of us who used to hold this power could not be shown to have accomplished so many disasters.

Darius emphasizes the Persian kings' divine mandate, contextualizing Salamis vis-à-vis a catalogue of Persian monarchs (765-779), none of whose conquests in any way predict or portend disaster on the scale that Xerxes has wrought. ${ }^{29}$ Between the chorus, Atossa, and the ghost, Xerxes is cast as an icon of unprecedented catastrophe, while his deceased father, by contrast, belongs to a long tradition of prosperous Persian monarchs whose success reflects divine support. While defeat in that tradition is not wholly wiped clean from the record, ideology and collective memory reinforce one another so as to make Xerxes an aberration - the exception to the rule. ${ }^{30}$

In marginalizing Xerxes, the Persians' attitude has come full circle, even as their worst fears, contrariwise, have been catastrophically realized. The reassertion of Darius as a figure of prosperity recalls his first mention in the play, a link that is underscored by the course of action the ghost prescribes to avoid further calamity. For, in order for the Persians to fare well, he advises, they must not launch further expeditions to Greece, since the very land there is an ally to the Greek people (790-792). As though to prove his point, he then predicts disasters that lie in the future (796-822)-i.e., Plataea-before summarizing his advice as follows:

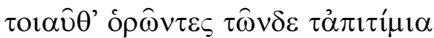

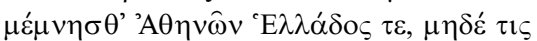

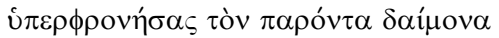

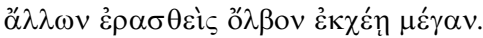

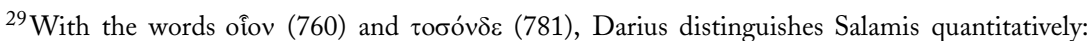
the extent of Xerxes' defeat is unparalleled. On the problematic inclusion of Artaphrenes in the list (778), see Garvie 2009: 300-301, ad 759-86. For Herodotus' treatment of Xerxes compared to his predecessors, see Boedeker 2012: 23-24.

${ }^{30}$ See further the chorus' praise of Darius as a $\pi \alpha v \tau \alpha \rho \kappa \eta े \varsigma ~ \alpha ̉ \kappa o ́ k \alpha \varsigma ~ \alpha ُ \mu \alpha \chi o \varsigma \beta \alpha \sigma \imath \lambda \varepsilon v ́ \varsigma$ ("king who is wholly sufficient, invincible, and who does no harm," 855) whose nostoi successfully led soldiers

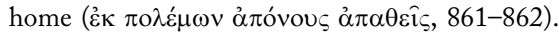


As you observe such a penalty for these actions, remember Athens and Greece, and let no one dump out our great prosperity out of desire for that of others, in disdain for our existing good fortune.

Remember Athens, he insists, and do not destroy Persian prosperity by seeking another's. Recalling Atossa's anxiety about the overturning of Persian prosperity at the start of the play (163-164), he asserts that Greece, in essence, should be off limits in the future.

Darius' prescriptions bring the issue of Persian memory (for my purposes at least) to its paradoxical conclusion. In asserting a wish that the Persians would remember Athens and resist both greed and the attraction of empire, he lays the foundation for future success. But coming from the ghost of Darius himself, and appearing as it does at the conclusion of a scene whose entire thrust is to reassert a specific memory of him as the latest in a series of semi-divine icons of imperial prosperity, the claim is jarring. For one, imperialism is essential to Persian ideology and is consistent, as we have observed, with what they understand as a divine mandate (762-764; cf. 101-107). Thus, at the core of the Persians' recollection of Darius' reign lie both the wealth he accumulated via conquest and his capable stewardship of military affairs (163-167, 652-656, 709-712, 780-781), just as amongst Xerxes' contradictory motivations for undertaking the expedition to Salamis is the example of his forebears' conquests (753-758). The cessation of campaigning advocated by Darius is as incompatible with Persian ideology as his prediction of further defeat at Plataea is - he might as well advocate the dissolution of the empire! The imperative to remember Athens is no less shocking for the paradox that lies at its heart: Darius' ghost prescribes the need to remember Athens, even as the Persian memory of his reign, as articulated by his own wife (231-245), would downplay his defeat at Marathon and the precedent it set for his son's failure. ${ }^{31}$ Atossa's decision to bring new garments to her son (849-850), similarly, reflects a desire to disguise the catastrophe. Because the ghost itself is complicit in this willful forgetfulness, the imperative "remember Athens" is wickedly ironic. ${ }^{32}$

Aeschylus' play should not be considered a historical source for how the Persians recalled Darius and Marathon or responded to Xerxes and Salamis, and I do not want to claim that his dramatic representation is at all fair to actual Persians. ${ }^{33}$ Persae is an Athenian production for an Athenian audience, and its interpretation must acknowledge the gulf between the memories of the dramatized Persians and the historical audience before which it was performed. My reading is catalyzed by the idea of collective memory, which historians and

\footnotetext{
${ }^{31}$ Kantzios (2004: 13) discusses various similarities between father and son known to the Athenian audience.

${ }^{32}$ So also Grethlein 2010: 85. Cf. Grethlein (2007: 378), who interprets the exhortation in more metapoetic terms.
}

${ }^{33}$ Cf. Hall 1989: 81-86. 
anthropologists describe as the means and manner in which a particular group or culture both remembers and, more importantly, renders the past usable: "social or collective memory ... creates collective identity by giving individuals a shared image of their past, providing them with an explanation of the present and a vision of the future." ${ }^{34}$ As far as the Persians are concerned, the mechanics of collective memory have been the focus of this paper: the handling of Darius' defeat at Marathon, I argued, was indicative of both a conception of a timeless present linking past and future as well as of an ideological confidence in conquest and imperial prosperity. What remains, however, is to consider what impact Aeschylus' dramatization might have had on his fellow Athenians' collective memory of the war, as well as to what vision of their future it might have lent support. ${ }^{35}$ Instead of memory in the play, one must consider as well the memory of the play and the memory constructed by the play.

Few would now question the idea that Attic tragedy, as part of a major public festival, was produced in a political context. ${ }^{36}$ The $470 \mathrm{~s}$ as a decade marks a particular watershed for the polis, witnessing the formation of the Delian League and the assumption of Athenian hegemony. Such is the context for the production of Persae in 472: eight years following victory at Salamis, Cimon was overseeing the league's operations in Thrace and the Aegean. Scholarly hindsight (with the knowledge of what lies ahead in the fifth century) takes a certain Athenian bullishness in this decade for granted, but one ought not to be overly confident regarding the popular mood. The day-to-day operation of democracy is messy business, and we must also allow for the democratic debate and factional strife that accompanied all deliberations over foreign and domestic policy in Athens (let alone amongst the allies). Cimon's rise to political prominence, for example, did not happen in a vacuum, ${ }^{37}$ and the formation, composition, and institutions of both the league and its activities demanded both the Athenians and her allies' attention. Within a few years of Persae's production (to provide a concrete example), as the league's financial obligations proved a heavy burden,

\footnotetext{
${ }^{34}$ Steinbock 2012: 7. See also Alcock 2002: 1; Fentress and Wickham 1992: 25.

${ }^{35}$ For collective memory's forward-looking posture, occasionally described in terms of a "useable past," see Steinbock 2012: 8, n. 22. In Benveniste's terms (1966), the poet is engaging in discours rather than récit: see the discussion of Boedeker (2012: 18), subsequently expanded to treat Herodotus and lyric. Grethlein (2010: 93-95) interprets the play's significance for an Athenian audience differently.

${ }^{36}$ See Goldhill 1990. Amongst other reasons, it is clear from the furor surrounding the performance of Phrynichus' Sack of Miletus described by Herodotus (6.21) that historical subject matter was particularly relevant to the public discourse. Debate about how Persae was received in Athens has oscillated between interpretations that view the play as celebratory triumphalism, or as a properly tragic catastrophe with which the audience could sympathize. Both have merit; no audience's response is homogeneous.

${ }^{37}$ Cimon's elevation to power came at Themistocles' expense (e.g., Plut. Cim. 5.5-6). Both figures would eventually be ostracized: on ostracism as a democratic mechanism for managing intraelite competition, see Forsdyke 2005: 144-177.
} 
Naxos would revolt. No less than the original decisions to assume hegemony and to impose fees on member poleis, bringing the recalcitrant island promptly to heel was not the sole option open to the league, as the later acceptance of cash instead of troops makes clear. ${ }^{38}$ As Kurt Raaflaub has argued, the era following the wars was one of immense socio-political and economic change in Athens, ${ }^{39}$ and given that such debates stand out even in the buildup to Marathon, ${ }^{40}$ one must assume that the early years of Athenian hegemony were similarly dominated by questions pertaining to all things Persian.

The realities of democratic debate can be detected beneath the surface of the Persae, and even if I doubt that Aeschylus' play advocates a particular policy explicitly, its characterization of the Persian dramatis personae nonetheless appears designed to steer the Athenian memory of, and response to, the Persian wars. For, with the families and friends of the veterans (not to mention the veterans themselves!) taking in the production, it is unthinkable that the Persians' reflections on Athens, which acknowledge Salamis but downplay Darius' defeat at Marathon, would not ring false: ${ }^{41}$ for the Athenians, Marathon in fact sets the precedent for Xerxes' catastrophe at Salamis. The timing of the play's production, as a result, seems calculated: eight years after the Athenian-led victory at Salamis, Persae imagines the Persian ideology of that time, and how it remembered Darius and Marathon a mere decade prior. If one imagines an orator making an argument to this effect before the assembly in 472, a messagepart question and part warning-appears: implied are the ideas that the Persians might be preparing another invasion, and that Xerxes' defeat, lamented so vociferously, might have been relegated to oblivion in the intervening years as Darius' is within the play. Such a message is far from hyperbolic paranoia: in an era in which the Delian League's activities in the Aegean under Cimon are ongoing and ultimate victory at Eurymedon is still a few years away, it is both appropriate and timely. ${ }^{42}$ Christopher Pelling, for example, wonders whether the Athenians had by this time gotten word of the Persian preparations for Eurymedon, the fear of which would certainly have prompted debate in the assembly. ${ }^{43}$ The play subtly posits, through its characterization of Persian ideology, the persistence of the Persian threat.

\footnotetext{
${ }^{38}$ See Plut. Cim. 11. One cannot help but think of the Mytilenian debate described by Thucydides in this context, as well.

${ }^{39}$ Raaflaub 1998.

${ }^{40}$ Raaflaub 2010: 225.

${ }^{41}$ On the rapidity with which the Athenians lionized the Marathonomachoi and other veterans from the Persian wars for political and ideological purposes in the 470s, see Loraux 2006: 94-96. Cf. Jung (2006: 27-125), who interprets the memorialization in various media as a much more gradual process.

${ }^{42}$ For the chronology, see Miller 1997: 9-12. Those who would interpret the play as a warning against Athenian imperialism go too far: for a summary of this camp, see Grethlein 2007: 375, n. 24. More interesting is the argument of Gehrke (2001: 302) that Marathon, and the self-image of Athens as protector that it forms, has "prescriptive force for future conduct."

${ }^{43}$ Pelling 1997: 12; McMullin 2001: 65.
} 
Contextualizing the play within the larger mechanism of democratic deliberation has the advantage of bypassing the interpretive morass that attempts with futility to ascertain Aeschylus' personal politics. ${ }^{44}$ Because the play was financed by the young Pericles and celebrates a victory at Salamis associated especially with Themistocles, it has long been tempting to mine the correlation for deeper significance. ${ }^{45}$ But doing so is probably wishful thinking and a mistake: for one thing, Pericles would have been appointed choregos immediately at the start of the eponymous archon's term, well in advance of the archon's selection of the competing playwrights. ${ }^{46}$ Although the mechanism for allotment of choregoi is unclear, there is no evidence that his assignment to Aeschylus' production was anything but an accident. But even were it not, the suggestion that the young choregos had any poetic (i.e., non-financial) input is, in a word, preposterous. ${ }^{47}$ My interpretation of the play, which is compatible with support for the campaigns of the Delian League (if not Cimon himself, as well ${ }^{48}$ ), would in any case complicate such a presumption. ${ }^{49}$ As regards Themistocles, whose ostracism occurred only a few years following the production, I am similarly suspicious: the play attributes both Siccinus' false message and the victory as a whole to Greeks who remain, individually and collectively, anonymous. The ruse may be Themistocles', but, as Garvie notes, the sentiment is Panhellenic. ${ }^{50}$ Though many are inclined, in light of the play's focus on the naval victory at Salamis, to see a pro-Themistoclean agenda at work, I see little indication of an authorial comment, or any propaganda, for that matter. ${ }^{51}$ The play's suppression of Marathon and fixation on Salamis, rather, belong to the thematization

${ }^{44}$ Garvie (2009: xviii-xix) provides a fine summary of the various camps in the debate. My caution reflects that of Harrison (2000: 25-39).

${ }^{45}$ The fact that the incipit of Persae echoes that of Phrynichus' Phoenissae, a play on much the same topic produced (by Themistocles, no less!) only a few years prior has added further fuel to the fire: see Sommerstein 2012: 102-103.

${ }^{46}$ See Wilson 2000: 51-55. Plutarch (Per. 7) describes Pericles as cautious and reclusive in his youth. If he was content to serve behind the scenes, he may have volunteered for the liturgy in advance of his selection.

${ }^{47}$ Pelling (1997: 10) is similarly skeptical.

${ }^{48}$ Some would question the possibility of a pro-Cimonian bent to the play on the basis of Plutarch's Life of Cimon, which hints, in the context of the City Dionysia of 468, that Cimon supported Sophocles (Cim. 8.7). Cf. Scodel (2012: 27-28), for whom Plutarch's story implies, rather, that dramatist and general were not associated previous to the competition. My hesitation about mining such connections for evidence of deeper politics persists.

${ }^{49}$ Admittedly, the play is not designed to advocate openly for Cimon's later interests, either: Persae suppresses both Marathon and Miltiades, memories which Cimon would work to restore in the decades to come. See Jung 2006: 109-125; Amandry 1960: 7-8.

${ }^{50}$ Garvie 2009: 182, ad 353-432; Rosenbloom 2011: 361-364; and Pelling 1997: 11. See also Thomas 1989: 202-217 on the typical anonymity of Athenian oral tradition, exemplified by funeral oration and its praise of the demos.

${ }^{51}$ My caution reflects that of Thomas (1989: 224-225), who is both unwilling to speculate on Cimon's politics and attitude toward Salamis, and skeptical of the extent to which Marathon and Salamis became politically charged symbols of the aristocracy and democracy, respectively. Cf. the speculations of Podlecki (1970: 7-8) and Hornblower (2011: 21). 
of memory and Persian ideology, and need not be explained with recourse to assumptions imported from outside the drama.

Persae is most certainly a political and topical play, but it is not propaganda. Because its themes of memory and history invite an Athenian audience to compare its reflections to those of the dramatis personae, the two sides' respective collective memories - memory in the play as well as the memory of the playshould both inform an interpretation. From the audience's perspective, any Persian forgetfulness not only promotes the memorialization and lionization of Athenian veterans, but also heightens wariness about the Persian threat. If the play has any agenda, it is to urge the Athenians not to make the Persians' mistake of forgetting their enemy: the dramatization of Persian collective memory, in other words, becomes the mechanism by which the past victories at Marathon and Salamis are put to the service of Athenian social memory. If one imagines once more the orator arguing before the democratic assembly, debates concerning the League or Athenian hegemony with which the play is engaging come into focus, as do the factions that variously espoused them. An argument emphasizing the Persian threat, after all, responds to any number of opposition parties lurking outside the text: the war-weary, ${ }^{52}$ those who were confident that the threat had already been sufficiently diminished, or those who hoped to pivot the polis' attention and energy toward the Peloponnese, instead. ${ }^{53}$ But however suggestive the play may have been (and I do not mean to suggest only a single takeaway message), it was left to the audience members to fill in gaps and details from their own memories, and to devise policy in the assembly based on their understanding of the war, of history, and of Persia. The use to which that collective memory was ultimately put, one can conclude, is perhaps on display in the Delian League of the 460s.

Department of Classics

220 Dysart RoAD

University of MaNitoba

Winnipeg, Manitoba

R3T 2M8

mike.sampson@umanitoba.ca

BIBLIOGRAPHY

Alcock, S.E. 2002. Archaeologies of the Greek Past: Landscape, Monuments, and Memories. Cambridge.

Amandry, P. 1960. "Sur les 'épigrammes de Marathon'," in F. Eckstein, (ed.), Theoria: Festschrift für W.-H. Schuchhardt. Baden-Baden. 1-8.

\footnotetext{
${ }^{52}$ On the increasing use of Athenian manpower, see Plut. Cim. 11; on the expense of maintaining the navy, see Raaflaub 1998: 17.

${ }^{53}$ On Athenian-Spartan relations following victory at Plataea, see especially Hornblower 2011: 8-12.
} 
Assmann, J. 1995. “Collective Memory and Cultural Identity,” New German Critique 65: 125-133 (orig. publ. in German in J. Assmann and T. Hölscher (eds.), Kultur und Gedächtnis [Frankfurt-am-Main 1988] 9-19).

Benveniste, E. 1966. Problèmes de linguistique générale. Paris.

Boedeker, D. 2012. "Past and Plupast in Elegy, Lyric, and Herodotus," in J. Grethlein and C. B. Krebs (eds.), Time and Narrative in Ancient Historiography: The Plupast from Herodotus to Appian. Cambridge. 17-34.

Bosher, K. 2012. "Hieron's Aeschylus," in K. Bosher (ed.), Theatre Outside Athens: Drama in Greek Sicily and South Italy. Cambridge. 97-111.

Burke, P. 1989. "History as Social Memory," in T. Butler (ed.), Memory: History, Culture and the Mind. Oxford. 97-114.

Csapo, E. and M. Miller. 1998. "Democracy, Empire, and Art: Toward a Politics of Time and Narrative," in D. Boedeker and K. Raaflaub (eds.), Democracy, Empire, and the Arts in Fifth-Century Athens. Cambridge. 87-125.

Dimopoulou, M. 2010. "The Athenians' Victory at Marathon in Aeschylus' Persae," in K. Buraselis and K. Meidani (eds.), Marathon: The Battle and the Ancient Deme. Athens. 237-250.

Fentress, J. and C. Wickham. 1992. Social Memory. Oxford.

Forsdyke, S. 2005. Exile, Ostracism, and Democracy. Princeton.

Garvie, A. F. ed. 2009. Aeschylus: Persae. Oxford.

Gehrke, H.-J. 2001. "Myth, History, and Collective Identity: Uses of the Past in Ancient Greece and Beyond," in N. Luraghi (ed.), The Historian's Craft in the Age of Herodotus. Oxford. 286-313.

Goldhill, S. 1990. "The Great Dionysia and Civic Ideology," in J. J. Winkler and F. I. Zeitlin (eds.), Nothing to Do with Dionysos? Athenian Drama in Its Social Context. Princeton. 97-129.

Grethlein, J. 2007. "The Hermeneutics and Poetics of Memory in Aeschylus' Persae," Arethusa 40: 363-396.

2010. The Greeks and Their Past. Cambridge.

Halbwachs, M. 1980. The Collective Memory. New York.

Hall, E. 1989. Inventing the Barbarian: Greek Self-Definition Through Tragedy. Oxford.

— ed. 2007. Aeschylus: Persians ${ }^{2}$. Warminster.

Harrison, T. 2000. The Emptiness of Asia: Aeschylus' Persians and the History of the Fifth Century. London.

Hopman, M. 2009. "Layered Stories in Aeschylus' Persians," in J. Grethlein and A. Rengakos (eds.), Narratology and Interpretation: The Content of Narrative Form in Ancient Literature. Berlin. 357-376.

Hornblower, S. 2011. The Greek World 479-323 B.c. ${ }^{4}$ New York.

Jung, M. 2006. Marathon und Plataiai: zwei Perserschlachten als "lieux de mémoire" im antiken Griechenland. Göttingen.

Kantzios, I. 2004. "The Politics of Fear in Aeschylus' Persians," CW 98: 3-19.

Loraux, N. 2006. The Invention of Athens: The Funeral Oration in the Classical City ${ }^{2}$. Tr. Alan Sheridan. New York and Cambridge.

McMullin, R. M. 2001. "Aspects of Medizing: Themistocles, Simonides, and Timocreon of Rhodes," CJ 97: 55-67.

Miller, M. C. 1997. Athens and Persia in the Fifth Century B.C.: A Study in Cultural Receptivity. Cambridge. 
Misztal, B. 2003. Theories of Social Remembering. Maidenhead.

Muntz, C. E. 2011. "The Invocation of Darius in Aeschylus' Persae," CJ 106: 257-271.

Pelling, C. 1997. "Aeschylus' Persae and History," in C. Pelling (ed.), Greek Tragedy and the Historian. Oxford. 1-19.

Podlecki, A. J. tr. and comm. 1970. The Persians by Aeschylus. Englewood Cliffs.

Raaflaub, K. A. 1998. "The Transformation of Athens in the Fifth Century," in D. Boedeker and K. Raaflaub (eds.), Democracy, Empire, and the Arts in Fifth-Century Athens. Cambridge. 15-41.

- 2010. "Herodotus, Marathon, and the Historian's Choice," in K. Buraselis and K. Meidani (eds.), Marathon: The Battle and the Ancient Deme. Athens. 221-235.

Rosenbloom, D. 2011. “The Panhellenism of Athenian Tragedy,” in D. M. Carter (ed.), Why Athens? A Reappraisal of Tragic Politics. Oxford. 353-381.

Saïd, S. 1981. "Darius et Xerxès dans les Perses d'Eschyle," Ktèma 6: 17-38.

Schenker, D. 1994. "The Queen and the Chorus in Aeschylus' Persae," Phoenix 48: 283-293.

Scodel, R. 2012. "Sophocles' Biography," in K. Ormand (ed.), A Companion to Sophocles. Malden. 25-37.

Sommerstein, A. H. 2010. Aeschylean Tragedy2. London.

— 2012. "The Persian War Tetralogy of Aeschylus," in D. Rosenbloom and J. Davidson (eds.), Greek Drama 4: Texts, Contexts, Performance. Oxford. 95-107.

Steinbock, B. 2012. Social Memory in Athenian Public Discourse: Uses and Meanings of the Past. Ann Arbor.

— 2013. "Contesting Lessons from the Past: Aeschines' Use of Social Memory," TAPA 143: 65-103.

Taplin, O. 1977. The Stagecraft of Aeschylus: The Dramatic Use of Exits and Entrances in Greek Tragedy. Oxford.

Thomas, R. 1989. Oral Tradition and Written Record in Classical Athens. Cambridge.

West, M. L. ed. 1998. Aeschyli Tragoediae quae supersunt cum incerti poetae Prometheo 2. Stuttgart.

Wilson, P. 2000. The Athenian Institution of the Khoregia: The Chorus, the City and the Stage. Cambridge. 